\title{
Disappeared persons and homicide in El Salvador
}

\author{
Carlos Carcach *iD and Evelyn Artola
}

\begin{abstract}
During 2012-2013, the homicide rate in El Salvador came down from 69.9 to 42.2 per 100,000 population following a government brokered truce between the leaders of the two major gangs, Mara Salvatrucha and Barrio 18. But despite the apparent successes of the truce, it was speculated that the drop in murders could have been due to the killers simply hid the bodies of their victims. This paper aims at determining whether gangs effectively disappeared their victims to cut down the official counts of murders, or they committed these crimes for other reasons. The results from this study suggest that Salvadoran gangs had been using disappearance as a method to gain sustained social control among residents of already gang-dominated areas, that together with homicide, disappearance is part of a process of territorial spread and strategic strengthening by which these groups are enhancing their capabilities to interfere in the alliances of Mexican drug trafficking organizations with Central American criminal organizations specializing in the trans-shipment of drugs and in providing access to local markets to distribute and sell drugs. Our findings show that the risk for disappearance has been large even before the truce was in place and that actually, it continues as such and going through a process of geographic expansion.
\end{abstract}

Keywords: El Salvador, Maras, Bayesian mapping, Trends in disappearance, Homicide trends, Bayesian shared component model

\section{Maras and violence in El Salvador}

El Salvador, together with Guatemala and Honduras, is part of the so called Northern Triangle of Central America, arguably the most violent region in the world. The country is affected by a strong mara presence and is part of the drug trafficking corridor linking South America to the United States. In this paper, the terms mara and gang are used interchangeably to refer to both the Mara Salvatrucha and Barrio 18, either Sureños or Revolucionarios.

Unlike other street gangs, the maras are hierarchical organizations that coordinate their criminal activities across the United States, Mexico and Central America; fight against the authorities and against each other, for control of turf and local distribution of drugs; and use violence both against rivals and within their own groups to maintain internal order (Bruneau 2011).

*Correspondence: ccarcach@esen.edu.sv

The Center for Public Policy, Escuela Superior de Economía y Negocios, Academic Building, Calle Nueva a Comasagua, Santa Tecla, El Salvador
Despite the widespread of maras in El Salvador, there is not an agreed figure, either official or otherwise, on the number of individuals belonging to or related to these groups. Over the years, estimates of the number of gangs and gang members have varied depending on the source. For instance and according to the National Civilian Police, there were 10,500 active gang members in 2005, but the extinct National Council of Public Safety counted approximately 39,000 (Kinnear 2009). In 2015, an estimated 55,000 persons were gang members, with an estimated 470,000 affiliated with the gangs, including family members, friends and helpers, organized in 560 clicas nationwide (Ellis 2015).

These groups are held responsible for at least $60 \%$ of all homicides committed in El Salvador (Wolf 2011) but also are involved, inter alia, in extortion, kidnapping, rape, and the local distribution of drugs. In recent years, maras have evolved into complex criminal organizations associated with the drug trafficking transport networks tied to Mexican cartels, and are in possession of "assault rifles, vehicles, safe houses, encrypted satellite phones and are 
even able to deploy drones to monitor the movements of police or rival gangs". Maras "enforce curfews, man roadblocks to control access to their neighborhoods, and decide who can sell or move drugs and where. The maras have become more like political military forces than street gangs" (Farah 2016).

In March 2012, the government brokered a truce between the Salvadorian maras during which the homicide rate dropped by half. However, it has been alleged that under the truce, the maras hid the large numbers of people still being killed by burying them in clandestine cemeteries. Forcible displacement and forced migration are other phenomena that have also been attributed to maras and criminal organizations such as drug transporters and cartels as well (Farah 2012; Stone 2012, 2013; Sánchez-Aiscorbe 2014; Cantor 2014; Ellis 2015).

National survey data show at least 12,600 and 29,400 disappearances in 2012 and 2014, respectively. The number of persons forced to change their place of residence due to threats increased from at least 29,500 in 2012 to 64,400 in 2014 (IUDOP 2012, 2015). According to Salvadorian authorities, a significant number of disappearances are related to gang activity, since many of the missing were in gangs, or friends or relatives of gang members (US Department of State 2016).

The role that organized crime groups, maras included, might play in generating these events is little-studied. In El Salvador, a link between disappearances and homicides remains a distinct possibility. One may consider these phenomena as arising from unobserved common sources. Though there are no reliable data on the attribution of both these crimes, media and official reports suggest that at least under the truce, the maras may have perpetrated most of the disappearances recorded by the Salvadorian authorities (Farah 2012; Ellis 2015).

Models of spatial variation in crime rates and other crime related outcomes use location as a surrogate for the mix of routine activities, environmental clues and conditions, and opportunity structures that may underlie geographic differences in risk. As many crimes share common risk factors, analyzing their joint spatial behavior may help in obtaining more evidence of real clustering in the risk surface than would be available from the analysis of a single type of crime.

This research investigates the hypothesis that both homicide and disappearance are outcomes from unobserved processes associated to a greater extent with geographic variations of mara related activities. We expect that a significant between-municipality variation in relative risk of disappearance be explained by its joint spatial variation with homicide through a common cause, namely maras. A Bayesian approach is implemented to account for the uncertainty due to the fact that the data cannot fully inform whether this expected strong correlation between homicides and disappearances is due to gang activity.

This paper contributes to the discussion of patterns of gang violence in Central America, particularly in El Salvador. It explores the joint spatio-temporal behavior of homicides and disappearances over 2010-2014, a period covering March 2012-April 2013, the 14 months under the gang truce.

The paper continues with a review of homicide rates showing their decline during the early truce, followed by a discussion on how forced disappearances explain this dip and how those relate to maras. Then, we review and analyze the data on forced disappearances using an unobserved component model. Presentation and discussion of results precede the conclusion. References and acknowledgements are included at the end of the paper.

\section{Pre-truce and post-truce homicide rates}

Figure 1 shows homicide rates computed over 4 consecutive government periods. The first running from June 1999 to May 2004, recorded 39.7 homicides per 100,000 population and was scenery to the so called "Strong Hand Plan" that was implemented in 2003 under President Francisco Flores with the main objective of breaking up of gangs. It contemplated joint actions by the national police (PNC) and the army. The rate increased to 58.8 over June 2004-May 2009 in which the newly elected government of President Antonio Saca implemented what they named as "Ultra Strong Hand" policy, a set of actions aimed at fighting gangs, drug trafficking and money laundering.

The homicide rate went up to 61.7 murders per 100,000 during the first half of the government period of President Mauricio Funes, June 2009-February 2012. From March 2012 to May 2013, the two major gangs, the Mara Salvatrucha and Barrio 18, negotiated a 15 month truce, allegedly facilitated by the government at the behest of

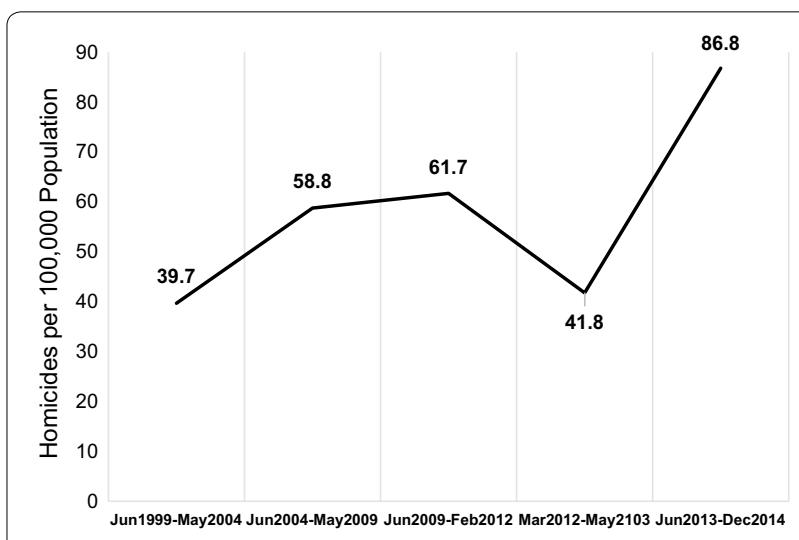

Fig. 1 El Salvador, homicide rates per 100,000 over different periods 
local drug traffickers and supported by the Organization of American States, under which the homicide rate felt down to 41.8. The truce aimed at reducing the numbers of murders in exchange for granting concessions to incarcerated gang leaders. The maras used the truce, particularly the MS-13, "to rearm, reorganize, build closer ties to regional cocaine transport networks, develop a political and economic strategy, and evolve from street gangs to criminal organizations with territorial and political control" (Farah 2016).

During the following 18 months, from June 2013 to December 2014, following the sitting of President Salvador Sánchez Cerén, who backed off from the truce and adopted a strategy based on a frontal combat to gangs, the homicide rate more than doubled to reach 86.8 per 100,000 residents.

\section{Disappearances and homicides}

The possibility that the decline in recorded homicide under the gang truce might have been accompanied by increases in the numbers of disappearances has been sustained by both the media and local crime and safety experts (Savenije and Van der Borgh 2014; Rivera Virúes 2014). In early 2014, the Instituto de Medicina Legal reported that during the truce, the number of disappeared had risen by an almost identical amount to the decline in the number of homicides. There is a strong belief that gangs used disappearances to bring homicide counts artificially down. Figure 2 shows police recorded cases of missing or disappeared persons per 100,000 population during each of the 5 years from 2010 to 2014. The rate went up from 60 in 2010 to 37.4 in 2014. In particular, it increased from 15.8 in 2011 to 26.1 in 2012 and to 30.7 in 2013 (i.e. the years when the gang truce was in place).

Figure 3 shows relative risks or standardized rates for both homicides and disappearances across municipalities and over time periods.

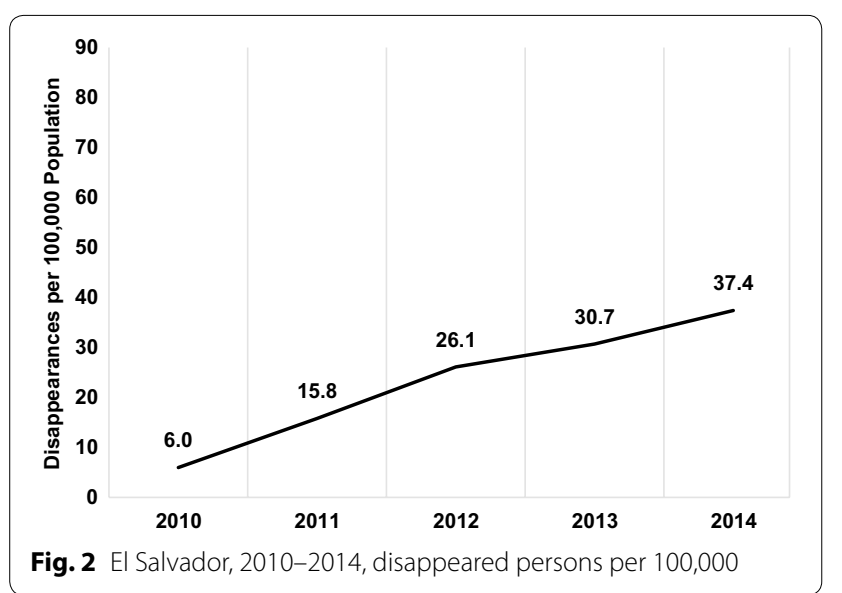

There were 81 municipalities with homicide risks exceeding one in 2010-2011 (first row and first column). Under the truce (i.e. 2012-2013), in 57 out of these municipalities, the risk dropped down to values that were smaller than one (second row and first column). On the other hand, in 2010-2011 there were 237 municipalities where the risk of disappearance took on values below one (first row and second column), 66 of which increased the risk to values greater than one during 2012-2013 (second row and second column). The maps in the third row of Fig. 3 show that following the end of the truce (2014), relative risks for both homicide and disappearance did not only increase but also seemed to have modified their geographical patterns.

\section{Disappearances and maras}

Disappearances are not a new phenomenon to Salvadorian society. At least 8000 persons disappeared during the civil war of 1980s (Commission on the Truth for El Salvador 1993). During the last 10 years or so, forceful disappearances have occurred within a context of intense gang activity, mainly by the Mara Salvatrucha and Barrio 18 gangs. The nature of gang-related disappearances is not clear cut. While it is true that the disappearance of a person implies her kidnapping, the most likely set up of most of the Salvadorian disappearances involves the murder and further clandestine burial by a gang, within the limits of a gangdominated territory. The apparent gain of political power by maras as evidenced by an enhanced capacity to negotiate with government, together with an undisputed control over significant parts of the country's territory and penitentiary facilities, may lead one to think of Salvadorian gangs as organizations that have evolved into a mix of mafia-like organizations and some form of politically motivated groups with characteristics that may be similar to those observed in paramilitary groups of Colombia and Mexico (Farah and Phillips Lum 2013; Ellis 2015).

The data in Figs. 2 and 3 provide support to the claim in Rivera Virúes (2014) that Salvadorian gangs are extending the use of the killing and secret burial of their victims. Initially and as a response to a government approach to crime control characterized by increased presence of police and army in the streets, gangs reduced the numbers of homicides committed in public places and replaced them with the clandestine burial of their victims.

Also and similar to forceful displacement (Cantor 2014) gangs might use disappearances to gain social control through either the intimidation of the residents of dominated territories, or ensuring their cooperation in protecting themselves against rival gangs or police. Demanding concessions from government to imprisoned gang members may be another factor underlying 

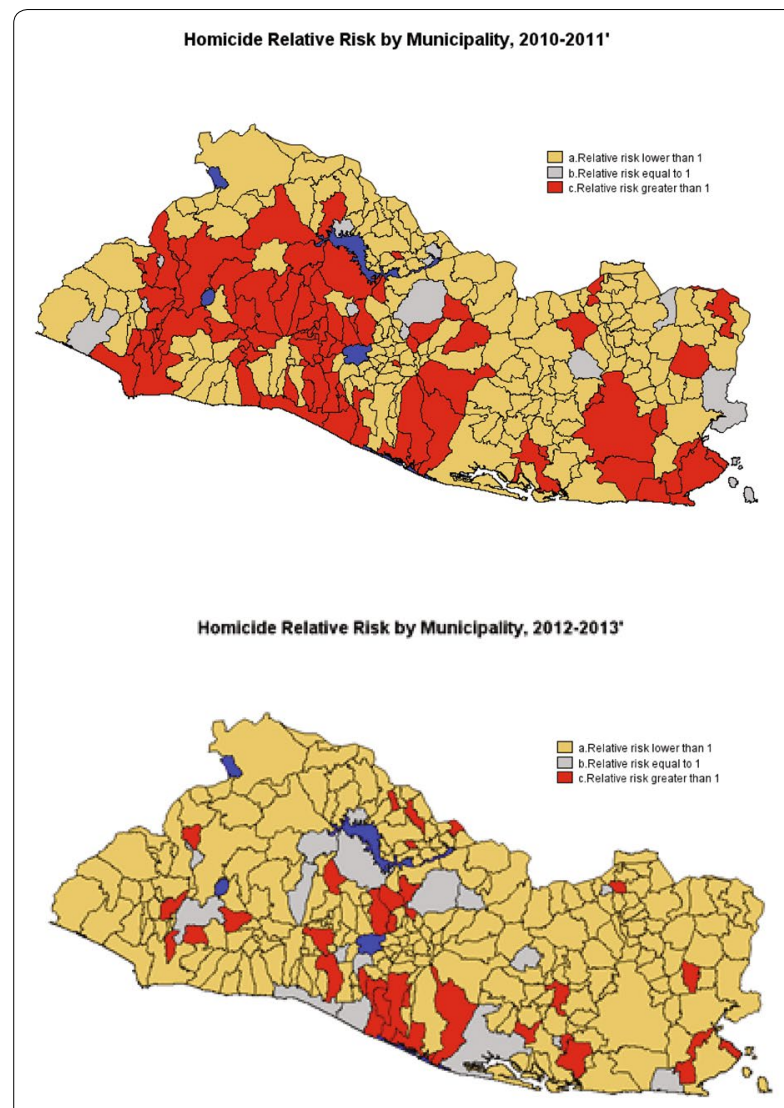

Homicide Relative Risk by Municipality, 2014

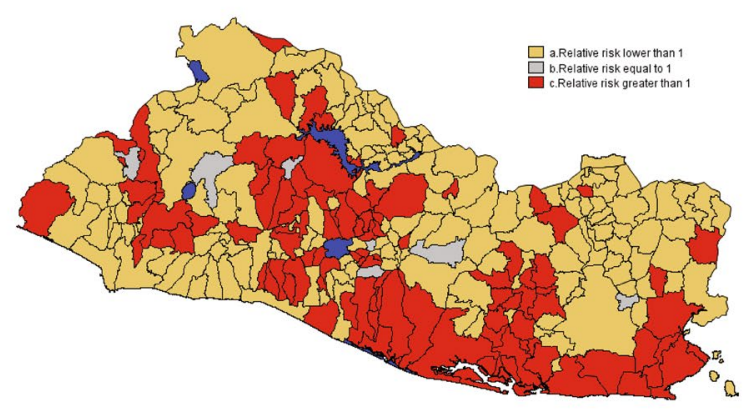

Missing persons andior disappearances Relative Risk by Municipality, 2010-2011*

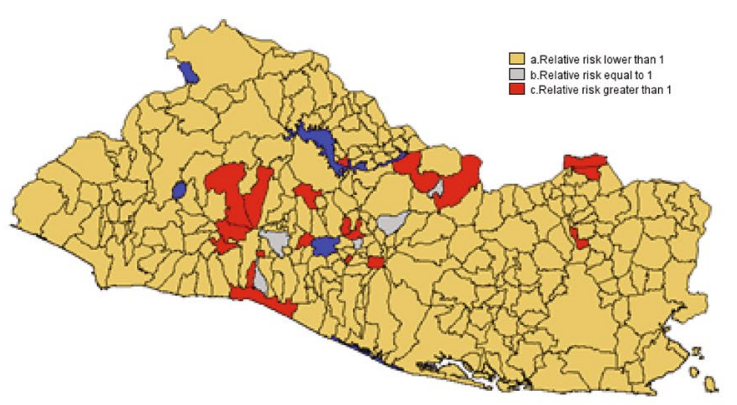

Missing persons and/or disappearances Relative Risk by Municipality, 2012-2013*

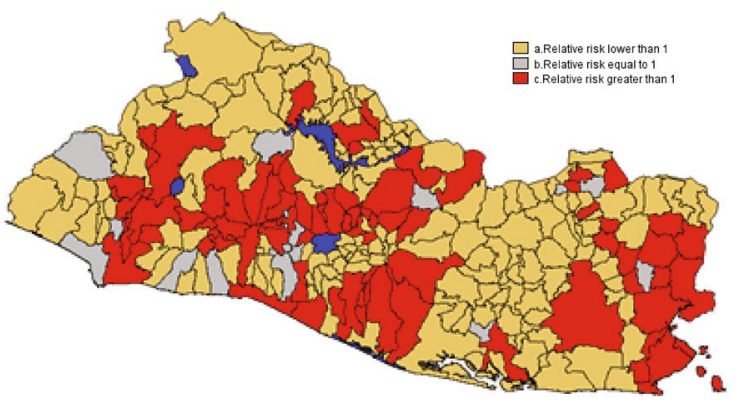

Missing persons and/or disappearances Relative Risk by Municipality, 2014

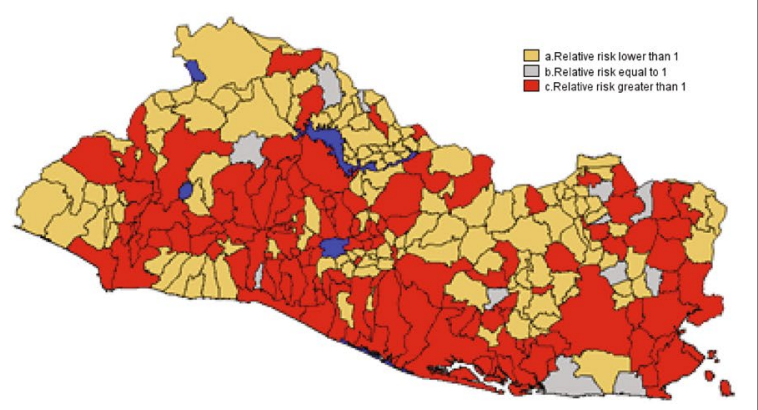

Fig. 3 Relative risk for homicide and disappearance

disappearances (Rivera Virúes 2014). In 2010-2012, the country suffered a wave of disappearances, mostly young people and teenagers, who went missing without explanation in a phenomenon linked to the gang violence hitting the country (Stone 2011, 2013; Sánchez-Aiscorbe 2014). In El Salvador, most accounts on this type of violence come from the media.

Outside the context of political violence and drug wars, in Latin America, the disappearance of persons has been related to paramilitary groups as in the case of Colombia (Rozema 2008; Hristov 2010), and the so called self-defense forces, as in Mexico (Santamaría 2014). Literature on disappearances related to gang activity is almost inexistent. Rivera Virués (2014) is the only academic work on the topic that also refers to the specific case of El Salvador.

Based on field research, Cantor (2014) analyzed the broad dynamics of the closely related phenomenon 
of forced displacement provoked by organized crime groups-maras, Central American drug transporters, and Mexican drug cartels. Structural differences between these groups influence both the forms of displacement that they produce and the resulting patterns of movement by displaced persons. The reasons underlying someone's disappearance, killing and secret burial might be similar to those causing displacement. Disappearance can be dealt with as an intermediate outcome in the process of population displacement caused by gangs.

Cantor (2014, p. 11) proposed two distinctive forms of population displacement: those resulting from the "everyday activities" of criminal groups; and those resulting from the periodic violent disputes between them. Regarding the former and from the standpoint of the criminal group, displacement may occur due to betrayal or enmity; resistance; land appropriation; and insecurity. Grounds for displacement related to the latter have to do with disputes between gangs, between Transportistas and between Mexican cartels. We pay attention to possible links between "everyday activities" of gangs and disappearances.

In El Salvador and at the national level, the Mara Salvatrucha and the Barrio 18 gangs are structured through prison-based "councils" of leaders that provide only broad direction to local groups of mara members known as clicas, each of which operates with a large degree of autonomy in its own territory. Gangs operate in urban and sub-urban areas and divide their territory into a cli$c a$ 's" core and "extended" zones of operation. Members of the clica live in the "core" zone that is located in one or more marginal urban neighborhood and from it carries localized criminal activities such as drug-dealing. These areas concentrate unusually large rates of violence. The "extended" areas are those where clicas enter more sporadically to extort businesses and sometimes residents, and where there is presence of public and private security. In "core" zones, the clicas ensure the support from local residents by imposing codes of conduct on them. Observance of these rules is backed up by violence and other control mechanisms (Cantor 2014, p. 7).

\section{On this research}

This paper uses data on official records of disappearances and homicides to explore joint spatial behavior across municipalities in El Salvador over the period 2010-2014. It aims at identifying spatial patterns to the practice of forced disappearances by maras by exploring their spatial correlation with homicides. We separate the underlying risk surface for each crime into a shared and a crime specific component. We predict the strongest effect of the unobserved shared component on the risk of disappearance.

\section{Methods}

A Bayesian model with shared components (Knorr-Held and Best 2001) was implemented to jointly account for the effect of unobserved common influences on the risk of both the disappearance of persons and homicide. This approach was deemed convenient as it was believed that most variation in relative risk was due to differences in gang activity across municipalities.

The data for this study consisted of the numbers of disappeared persons and homicides occurring at each of the 262 municipalities across the country over the 5 year period spanning from 2010 to 2014. Data on homicides were obtained from the Instituto de Medicina Legal, and data on disappeared persons came from the Policía Nacional Civil. Official population projections obtained from the Dirección General de Estadistica y Censos were used in the computation of rates. We analyze the data over three periods: 2010-2011 (prior to the gang truce), 2012-2013 (under the truce), and 2014 (following the end of the truce).

Let the $i$ index designate a municipality, $(i=1,2, \ldots, 262)$, and the $k$ index, a specific outcome, $k=1$ for disappearance and 2 for homicide. The number of incidents in municipality $i$ for outcome $k, Y_{i k}$, follows a Poisson distribution with mean $E_{i k} \theta_{i k}$. In this expression, $\theta_{i k}$ is the unknown relative risk of person disappearance or homicide and $E_{i k}$ is the expected number of disappeared persons or homicides in municipality $i$. Risks are estimated by (indirectly) standardized rates (SRs). In order to implement the Bayesian approach to the modeling of disappearance and homicide risk, a same Poisson distribution was assumed at the first level of hierarchy, given by

$$
Y_{i k} \mid \theta_{i k} \sim \operatorname{Poisson}\left(E_{i k} \theta_{i k}\right)
$$

The use of SRs as estimates of relative risk assumes a constant rate over each local area and outcome. For rare events such as disappearances or homicides, the variation in the numbers of incidents exceeds that predicted by a Poisson process. Extra variation may arise either from common unobserved heterogeneity that may be dominated by gang activity, or from the spatial clustering of incidences, or both. Allowing area-specific risks to depend on a latent variable (a random effect), the variance of which reflects the degree of extra-Poisson variation, is a standard approach to accommodate overdispersion in counts in the epidemiological literature (Mollié 2000; Lawson 2013 and references therein).

At the second level of the hierarchy, the logarithms of the relative risks were defined as

$$
\log \left(\theta_{i 1}\right)=\alpha_{1}+\delta W_{i}+U_{i 1}, \text { for disappearance, }
$$

and

$$
\log \left(\theta_{i 2}\right)=\alpha_{2}+\frac{W_{i}}{\delta}, \text { for homicide. }
$$


In these expressions, $U_{1 i}$ is a separate random component for disappearance, $W_{i}$ represents the shared component, and $\alpha_{1}$ and $\alpha_{2}$ are specific intercepts for disappearance and homicide, respectively. Finally, $\delta$ is a scaling component for the contribution of the shared component to the overall relative risk that allows for differential risk gradients (on the log-scale) for each crime.

Prior distributions needed to be assigned to the parameters. The $\alpha$ parameters were assigned improper uniform priors on the whole real line. The choice of these priors expressed the absence of genuine prior expectations on the parameter values. A normal prior with zero mean and variance $\sigma^{2}{ }_{\delta}$ was given to the logarithm of the scaling parameter $(\delta)$.

Conditionally autoregressive (CAR) priors (Besag et al. 1991) were used for the spatially structured random effects $\left(U_{1 i}\right)$ and the common component random effect $\left(W_{i}\right)$. Under the CAR specification and for a given municipality, the mean of $U_{1 i}$ and $W_{i}$ depends upon the $U_{1 i}{ }^{\prime} s$ and $W_{i}^{\prime} s$ of its neighboring municipalities. More formally,

$$
U_{1 i} \mid U_{1 j}, j \neq i, \tau_{u} \sim \operatorname{Normal}\left(\bar{U}_{1 i}, \sigma_{u i}^{2}\right),
$$

and

$$
W_{i} \mid W_{j}, j \neq i, \tau_{W} \sim \operatorname{Normal}\left(\bar{W}_{i}, \sigma_{W i}^{2}\right),
$$

where, $\bar{U}_{1 i}=\frac{1}{m_{i}} \sum_{j \neq i} \omega_{i, j} U_{j}, \bar{W}_{i}=\frac{1}{m_{i}} \sum_{j \neq i} \omega_{i, j} W_{j}, \sigma_{u i}^{2}=\frac{\sigma_{u}^{2}}{m_{i}}$, and $\sigma_{W i}^{2}=\frac{\sigma_{W}^{2}}{m_{i}}$, with $\omega_{i, j}=1$ if the $i$-th and $j$-th municipalities were neighbors and $m_{i}$ was the number of municipalities that were neighbors to the $i$-th municipality.

Variance parameters $\sigma_{u}^{2}$ and $\sigma_{w}^{2}$ control the variability of the random effects $U_{i}$ and $W_{i}$ conditional upon the random effects in the neighboring municipalities, respectively. At the next level of hierarchy, uniform hyper-priors (i.e. $U(0,10))$ were assigned to the variance parameters $\left(\sigma_{w}^{2}, \sigma_{u}^{2}\right)$.

We fitted the model in (1) and (2) to data on disappearances and homicide for three separate time periods. The first of these periods, 2010-2011, preceded the gang truce; the second, 2012-2013, corresponded to the time when the truce was in place; and 2014, when the truce was over.

The model was fitted using WinBUGS (Lunn et al. 2000), a programming language based software implementing MCMC algorithms to generate random samples from posterior distributions. The WinBUGS code for the model in (1) and (2) is available on request from the first author. Two chains were run and convergence was achieved by 20,000 iterations. A further 20,000 samples were run for each chain to obtain the desired posteriors with Monte Carlo errors lower than 5\% of the posterior standard deviation.

The general structure of the shared component model in (1) and (2) is discussed in Lawson (2013, p. 209). Earnest et al. (2010), MacNab (2010) and Chamanpara et al. (2015) are examples of recent applications in epidemiology. To the best of our knowledge and at the time of writing, the literature does not report on uses of this type of models in criminology.

From a criminological perspective, the shared common spatial component helps in understanding likely shifts in gang related violence to an increased use of the disappearance and further murder of individuals to either respond to police operations, or to adapt to new developments in drug markets or organized crime activities, or securing the control of territories, or all of the above.

\section{Results and discussion}

The deviance information criterion (DIC) (Spiegelhalter et al. 2002) was used to assess the fit and identification of the model in (1-2) relative to a simpler model without a shared component. Models with smaller DIC are considered better. For each of the three periods, the shared component model had smaller DIC scores compared to separate models for disappearance and homicide (Table 1).

Table 2 details the model parameters from the shared component model. For disappearances, the ratio of relative risk associated with the shared component was found to be 1.85 (95\% CI 1.04-4.00) in 2010-2011, 1.40 (95\% CI $0.99-2.23$ ) in $2012-2013$, and 1.97 (95\% CI 1.32-3.63) in 2014 , indicating that unobserved gang activity common to both outcomes has a strong association with the disappearance of persons. The model also shows that 79, 46 and $66 \%$ of the between-municipality variation in relative risk of disappearance is explained by the shared component during 2010-2011, 2012-2013 and 2014, respectively. These figures indicate the presence of a strong spatial pattern in both homicide and disappearance.

The delta coefficient measuring the spatial correlation of homicide and disappearance took on values of 0.71 (95\% CI $0.42-0.99$ ) in $2010-2011,0.84$ (95\% CI $0.67-1.00)$ in $2012-2013$, and 0.73 (95\% CI 0.59-0.87) in 2014 , a result supporting the hypothesis that both homicide and disappearance are outcomes from unobserved processes associated with geographic variations of mara related activities (see last row of Table 2). As expected, the correlation of homicide and disappearances was strongest in 2012 the year the gang truce was in place (0.84) but this coefficient was large before the truce $(0.71$ in 2010-2011) and remained as such after the truce was over (0.73 in 2014). 
Table 1 Summary of deviance information criteria for competing models

\begin{tabular}{|c|c|c|c|c|c|c|}
\hline & \multicolumn{2}{|c|}{$2010-2011$} & \multicolumn{2}{|c|}{$2012-2013$} & \multicolumn{2}{|l|}{2014} \\
\hline & $\mathrm{pD}$ & DIC & $\mathrm{pD}$ & DIC & $\mathrm{pD}$ & DIC \\
\hline \multicolumn{7}{|c|}{ Shared component model } \\
\hline Disappearances & 118.51 & 811.00 & 142.44 & 1190.72 & 141.19 & 1091.74 \\
\hline Homicide & 187.69 & 1495.18 & 145.82 & 1391.65 & 162.92 & 1313.77 \\
\hline Total & 306.19 & 2306.18 & 288.26 & 2582.38 & 304.11 & 2405.51 \\
\hline \multicolumn{7}{|l|}{ Individual models } \\
\hline Disappearances & 120.85 & 815.95 & 144.41 & 1203.09 & 144.39 & 1104.28 \\
\hline Homicide & 189.46 & 1496.30 & 151.28 & 1398.65 & 166.30 & 1318.35 \\
\hline
\end{tabular}

Table 2 Summary of model parameters

\begin{tabular}{|c|c|c|c|c|c|c|c|c|c|}
\hline & \multicolumn{3}{|c|}{$2010-2011$} & \multicolumn{3}{|c|}{ 2012-2013 } & \multicolumn{3}{|l|}{2014} \\
\hline & Estimate & $\begin{array}{l}\text { Lower bound } \\
95 \% \mathrm{Cl}\end{array}$ & $\begin{array}{l}\text { Upper bound } \\
95 \% \mathrm{Cl}\end{array}$ & Estimate & $\begin{array}{l}\text { Lower bound } \\
95 \% \mathrm{Cl}\end{array}$ & $\begin{array}{l}\text { Upper bound } \\
95 \% \mathrm{Cl}\end{array}$ & Estimate & $\begin{array}{l}\text { Lower bound } \\
95 \% \mathrm{Cl}\end{array}$ & $\begin{array}{l}\text { Upper bound } \\
95 \% \mathrm{Cl}\end{array}$ \\
\hline $\begin{array}{l}\text { Average } \\
\text { logarithm of } \\
\text { municipal- } \\
\text { level risk of } \\
\text { disappear- } \\
\text { ance-exp } \\
\left(a_{1}\right)\end{array}$ & 0.144 & 0.115 & 0.174 & 0.684 & 0.619 & 0.748 & 0.887 & 0.787 & 0.990 \\
\hline $\begin{array}{l}\text { Average } \\
\text { logarithm of } \\
\text { municipal- } \\
\text { level risk of } \\
\text { homicide- } \\
\exp \left(a_{2}\right)\end{array}$ & 0.677 & 0.631 & 0.719 & 0.538 & 0.507 & 0.571 & 0.795 & 0.741 & 0.852 \\
\hline $\begin{array}{l}\text { Ratio-Rela- } \\
\text { tive Risk } \\
\text { associated } \\
\text { with shared } \\
\text { component }\end{array}$ & 1.85 & 1.04 & 4.00 & 1.40 & 0.99 & 2.23 & 1.97 & 1.32 & 3.64 \\
\hline $\begin{array}{l}\text { Fraction of } \\
\text { variation in } \\
\text { RR of disap- } \\
\text { pearance } \\
\text { explained } \\
\text { by shared } \\
\text { component }\end{array}$ & 0.79 & 0.66 & 0.83 & 0.46 & 0.42 & 0.48 & 0.66 & 0.63 & 0.67 \\
\hline $\begin{array}{l}\text { Delta coef- } \\
\text { ficient } \delta\end{array}$ & 0.71 & 0.42 & 0.99 & 0.84 & 0.67 & 1.00 & 0.73 & 0.59 & 0.87 \\
\hline
\end{tabular}

For disappearance, municipal-level relative risks have varied around average values of $0.144,0.684$ and 0.887 during 2010-2011, 2012-2013 and 2014, respectively. In the case of homicide, municipal-level relative risks have varied around average values of $0.677,0.538$ and 0.795 over the same periods. These estimates suggest a convergence in national average relative risks of disappearance and homicide over time.

Figure 4 displays the overall posterior mean relative risk from the shared component model for both homicide and disappearance. The data suggest that prior to the gang truce (i.e. 2010-2011), the relative risk for disappearance was larger in municipalities that also had large relative risks for homicide, most of them located in the central part of the country. During the truce (i.e. 2012-2013), the relative risk for homicide concentrated in a few municipalities located along the Pacific coast and one municipality located in the North-Eastern region. On the other hand and always during the time the gang truce was in place, the relative risk for disappearance 

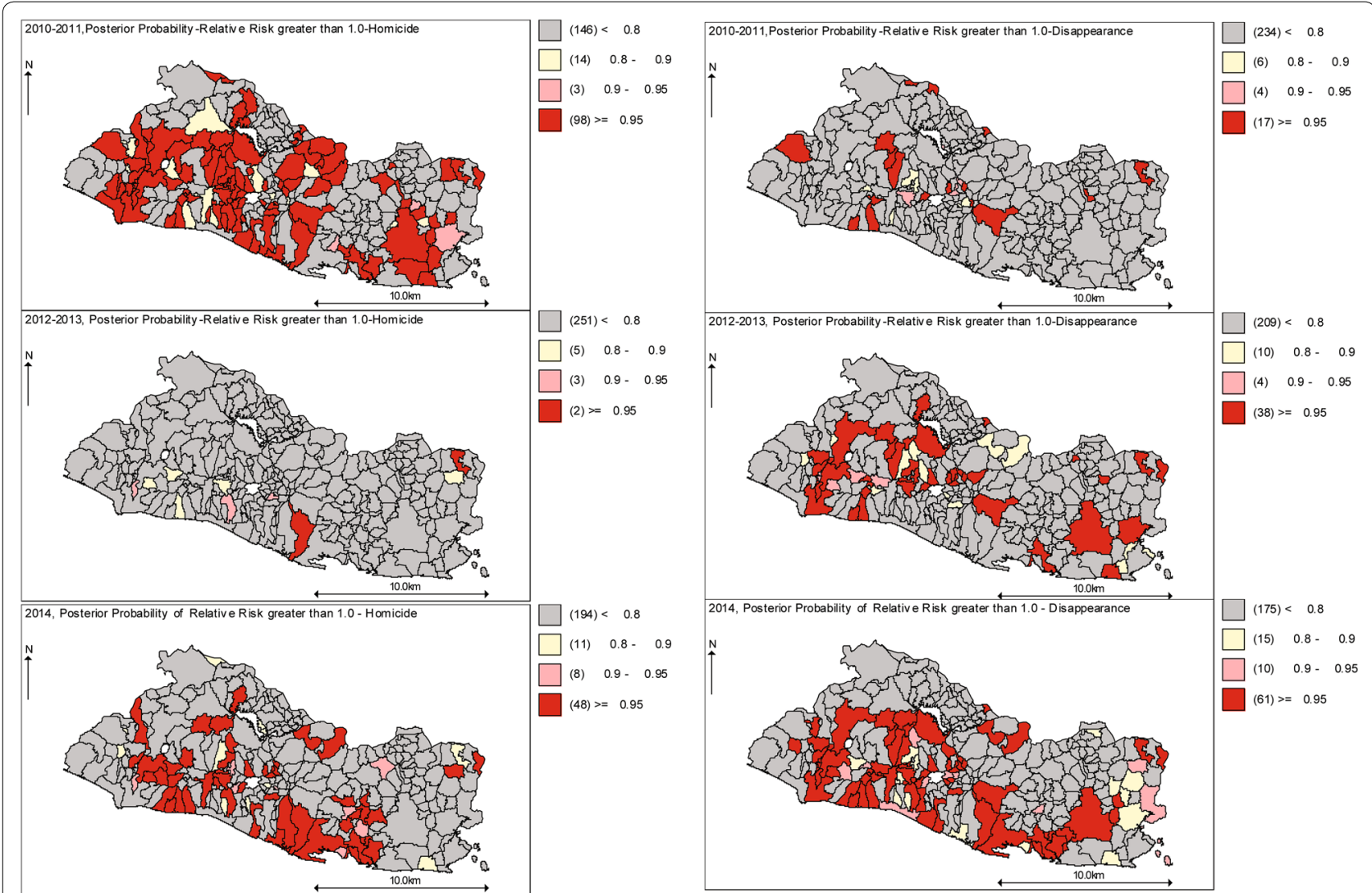

Fig. 4 Posterior median relative risks for disappearance and homicide in El Salvador from the shared component model

not only continued being large for many of the municipalities where it also was large in the previous period (i.e. 2010-2011), but spread over municipalities located in the Eastern side of El Salvador. Finally, the maps in the last row of Fig. 4 indicate that after the truce was over, homicide risk recovered the spatial distribution it had during 2010-2011 whereas the risk of disappearance continued spreading over the territory.

These results suggest that in gang-dominated areas, the risk for disappearance has been large even before the truce was in place and that actually, it continues as such and going through a process of geographic expansion. These findings are consistent with an explanation of the phenomenon as a component of a strategy aimed at gaining sustained social control among residents of already gang controlled areas. According to the Salvadorian police, nearly $90 \%$ of disappeared persons are murdered by gangs. Clandestine graves are the final destination of most persons going disappeared. During 2007-2013, the Fiscalía General de la República conducted 145 inhumations in 30 clandestine cemeteries. Around 2007-2009, cemeteries were located in semi-rural deprived and gangcontrolled communities of municipalities of the San Salvador metropolitan area. During 2009-2010, clandestine graves were discovered in the rural areas of the municipalities of Santa Ana and Usulután, located in the Western and Eastern sides of the country, respectively. Between 2011 and 2013, clandestine cemeteries were found in most of the territory indicating an expansion of the phenomenon (Rivera Virúes 2014, p. 61-62; Farah, 2016).

Figure 5 displays relative risk associated with the shared component. The maps might be taken as estimates of the evolution of the spatial distribution of gangs in El Salvador during 2010-2014. The data provide support to an explanation of violence as part of a process of territorial expansion and strengthening by maras to enhance their capabilities to interfere in the likely alliances of Mexican drug trafficking organizations with Central American criminal organizations specializing in the trans-shipment of drugs and in providing access to local markets to distribute and sell drugs (Dudley 2011; Santamaría 2014; Farah 2016).

\section{Conclusion}

This research implemented a Bayesian shared component model across municipalities of El Salvador to identify spatial patterns to the practice of forced disappearances by maras by exploring their spatial correlation 

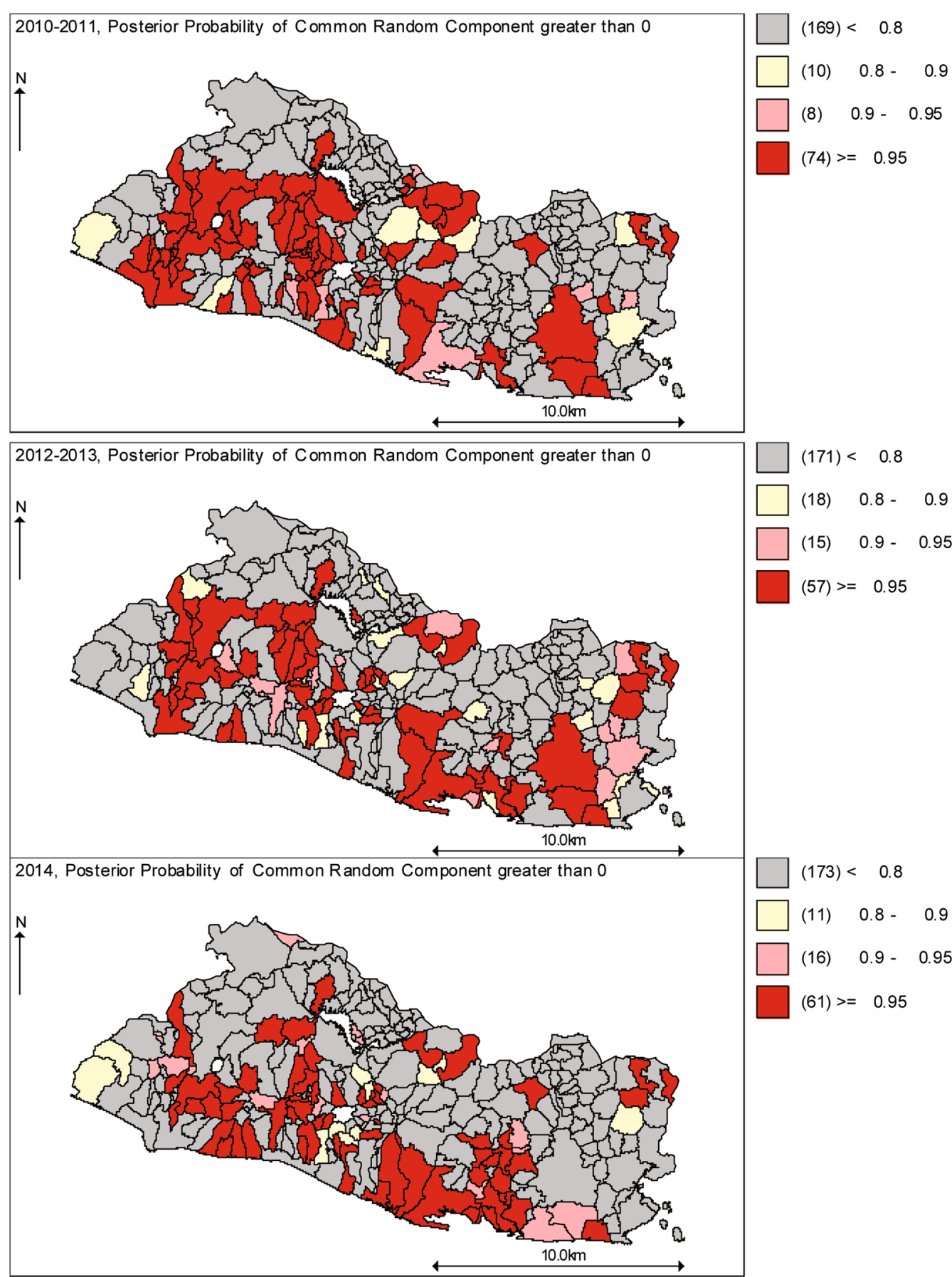

Fig. 5 Shared relative risk

with homicides. We separated the underlying risk surface for each crime into a shared component, namely mara activity, and a crime specific component. We used data for three periods-before the truce (2010-2011), under the truce (2012-2013), and after the truce (2014)-to examine the hypothesis that most spatial variation in the relative risk of both homicide and disappearance is due to differences in unobserved gang activity across municipalities.

In 2012-2013, the El Salvador's government allegedly brokered a truce between the Mara Salvatrucha and the Barrio 18 gang. Police data reveal that during the truce, homicides dropped by half. It has been argued that this decrease was not real due to large amounts of 
disappeared persons. Police statistics indicate that the numbers of disappearances almost doubled during 20122013. It has been argued that the maras hid the large numbers of people still being killed by burying them in clandestine cemeteries.

The correlation of homicide and disappearances was strongest in 2012 the year the gang truce was in place but it was already large before the truce and remained as such after the truce was over. This finding suggests thatcontrary to widely cited claims-Salvadorian maras did not initiate disappearances during the truce as a means of keeping the homicide rates low but there is a wider pattern to the practice of forced disappearances by these groups. This seems to be part of a strategy by maras to induce loyalty among members and other residents of their territorial strongholds, ensure compliance with systematic extortion demands and with mara codes seeking to eradicate alternative power structures as well.

Our findings show that as expected, there is a strong spatial pattern in both homicide and disappearance, and that most of this variation is associated with variations of mara related activities. These activities concentrate in geographical corridors connecting municipalities located along key drug-trafficking routes.

In El Salvador and since the truce, the risk for disappearance has continued extending over greater areas of the territory, a fact that suggests a wider pattern to the practice of forced disappearances by maras. Both forced disappearance and homicide are key parts of a process of territorial expansion by which maras enhance their capabilities to interfere in the alliances of Mexican drug trafficking organizations with Central American criminal organizations. These groups specialize in the trans-shipment of drugs and in providing access to local markets to distribute and sell drugs.

The main policy implication deriving from this research has to do with the need for the Salvadorian government to regain the territorial and social control of expanding portions of the country. Either the Mara Salvatrucha or the Barrio 18 or both gangs seem to be involved in a conflict around the control of drug transport and distribution routes that are managed by other criminal organizations, allegedly linked to the Mexican drug trafficking groups and that most probably hold strong connections with locals.

\section{Authors' contributions}

CC designed the study, wrote the WinBugs code, conducted the statistical analyses, interpreted the results and drafted the manuscript. EA wrote, revised and implemented the WinBugs code, and helped interpreting the results and drafting the manuscript. Both authors read and approved the final manuscript.

\section{Acknowledgements}

The authors express thanks to the anonymous reviewers for their insightful and constructive comments.
Competing interests

Both authors declare that they have no competing interests.

Received: 27 January 2016 Accepted: 19 November 2016

Published online: 01 December 2016

\section{References}

Besag, J., York, J., \& Mollié, A. (1991). Bayesian image restoration with applications in spatial statistics (with discussion). Ann Inst Math Stat, 43, 1-59.

Bruneau, T. (2011). Introduction. In T. Bruneau, L. Dammert, \& Skinner, E (Eds.) Maras: Gang Violence and Security in Central America (pp. I-19). Austin: University of Texas Press.

Cantor, D. J. (2014). The new wave: Forced displacement caused by organized crime in Central America and Mexico. Refugee survey quarterly. http://rsq.oxfordjournals.org/content/early/2014/06/10/rsq.hdu008.full. pdf + html. Accessed 13 Nov 2015.

Chamanpara, P., Moghimbeigi, A., Faradmal, J., \& Poorolajal, J. (2015). Joint disease mapping of two digestive cancers in Golestan Province, Iran using a shared component model. Osong Public Health Res Perspect, 6(3), 205-210

Commission on the Truth for El Salvador. (1993).From madness to hope: the 12-year was in El Salvador. Report of the Commission on the Truth in El Salvador. UN Security Council, Annex S/25550.

Dudley, S. S. (2011). Drug trafficking organizations in Central America: Transportistas, Mexican cartels and maras. In C. J. Arson and E. L. Olson (Eds.), Organized crime in Central America: The Northern triangle (pp. 104-139). Woodrow Wilson Center Reports on the Americas \# 29. Washington DC: Woodrow Wilson International Center for Scholars.

Earnest, A., Beard, J. R., Morgan, G., Lincoln, D., Summerhayes, R., Donoghue, D., et al. (2010). Small area estimation of sparse disease counts using shared component models-application to birth defect registry data in New South Wales, Australia. Health Place, 16, 684-693.

Ellis, R. E. (2015).The gang challenge in El Salvador: worse than you thought. War on the Rocks. http://warontherocks.com/2015/12/the-gang-challenge-in-el-salvador-worse-than-you-can-imagine/. Accessed 2 July 2016.

Farah, D. (2012). The transformation of El Salvador's gangs into political actors. Hemisphere Focus. Centre for Strategic and International Studies. Washington DC. https://www.csis.org/analysis/transformation-el-salvadorsgangs-political-actors. Accessed 2 July 2016.

Farah, D. (2016). Central American gangs are all grown up. Foreign Policy. http://foreignpolicy.com/2016/01/19/central-americas-gangs-are-allgrown-up/. Accessed 14 June 2016.

Farah, D., Phillips Lum P. (2013). Central American gangs and transnational criminal organizations. The changing relationships in a time of turmoil. International Assessment and Strategic Center. Washington DC. http:// www.strategycenter.net/research/publD.302/pub_detail.asp. Accessed 2 July 2016.

Hristov, J. (2010). Self-defense forces, warlords or criminal gangs? Towards a new conceptualization of Paramilitarism in Colombia, labour, capital and society, 43:2, 2010. http://www.yorku.ca/cerlac/Hristov.pdf. Accessed 20 Nov 2015.

IUDOP (Instituto Universitario de Opinión Pública). (2012). Encuesta de evaluación año 2012. Consulta de Opinión Pública, Noviembre 2012. Universidad Centroamericana. Universidad Centroamericana José Simeón Cañas. San Salvador. http://www.uca.edu.sv/publica/iudop/archivos/informe131.pdf. Accessed 15 June 2016.

IUDOP (Instituto Universitario de Opinión Pública). (2015). Encuesta de evaluación año 2014. Consulta de Opinión Pública, Noviembre 2014. Universidad Centroamericana José Simeón Cañas. San Salvador. http://www. uca.edu.sv/iudop/wp-content/uploads/INFORME-137.pdf. Accessed 15 June 2016.

Kinnear, K. L. (2009). Gangs: a reference handbook. 2nd Edition. (Contemporary World Issues). Santa Barbara: ABC CLIO.

Knorr-Held, L., Best, N. (2001). Shared component models for detecting joint and selective clustering of two diseases. J R Stat Soc. https://epub.ub.unimuenchen.de/1573/1/paper_183.pdf. Accessed 20 Nov 2015.

Lawson, A. B. (2013). Bayesian disease mapping: hierarchical modeling in spatial epidemiology. Boca Raton: CRC Press. 
Lunn, D. J., Thomas, A., Best, N., \& Spiegelhalter, D. (2000). WinBUGS-a Bayesian modelling framework: concepts, structure, and extensibility. Stat Comput, 10, 325-337.

MacNab, Y. C. (2010). On Bayesian shared component disease mapping and ecological regression with errors in covariates. Stat Med, 29(11), 1239-1249.

Mollié, A. (2000). Bayesian mapping of Hodgkin's disease in France. In J. P. Elliot, J. C. Wakefiled, N. G. Best and D. J. Briggs (Eds.), Spatial epidemiology. Methods and applications (pp. 267-285). Oxford: Oxford University Press.

Rivera Virúes, J. J. (2014). Pandillas, Desaparición de Personas y Derechos Humanos en El Salvador. Unpublished master's thesis, Facultad Latinoamericana de Ciencias Sociales, México. http://bibdigital.flacso.edu. mx:8080/dspace/handle/123456789/5477. Accessed 15 Nov 2015.

Rozema, R. (2008). Urban DDR-processes: paramilitaries and criminal networks in Medellín, Colombia. J Lat Am Stud, 40(3), 423-452.

Sánchez-Aiscorbe, M. (2014). Why are so many young boys disappearing in El Salvador? Aljazeera America. http://america.aljazeera.com/watch/shows/ america-tonight/articles/2014/9/25/why-are-so-many-youngboysdisappearinginelsalvador.html. Accessed 20 Nov 2015.

Santamaría, G. (2014). Drugs, gangs and vigilantes: how to tackle the new breeds of Mexican armed violence. Norwegian Peacebuilding Resource Centre. http://www.clingendael.nl/sites/default/files/Santamaria_ NOREF_Drugs,_gangs_and_vigilantes_December_2014.pdf. Accessed 20 Nov 2015

Savenije, W., Van der Borgh, C. (2014). Anti-gang policies and gang responses in the Northern triangle the evolution of the gang phenomenon in Central America. The broker online. http://www.thebrokeronline.eu/ Articles/Anti-gang-policies-and-gang-responses-in-the-Northern-Triangle. Accessed 20 Nov 2015.
Spiegelhalter, D. J., Best, N. G., Carlin, B. P., \& Van der Linde, A. (2002). Bayesian measures of model complexity and fit (with discussion). J R Stat Soc Series B Stat Methods, 64, 583-640.

Stone, H. (2011). As gang violence hits El Salvador, a new wave of disappearances. The Christian science monitor. http://www.csmonitor.com/World/ Americas/Latin-America-Monitor/2011/1007/As-gang-violence-hits-ElSalvador-a-new-wave-of-disappearances. Accessed 20 Nov 2015.

Stone, H. (2012). El Salvador sees drop in murders but rise in disappearances. The Christian science monitor. http://www.csmonitor.com/World/ Americas/Latin-America-Monitor/2012/0522/El-Salvador-sees-drop-inmurders-but-rise-in-disappearances. Accessed 2 July 2016

Stone, H. (2013). The murky question of disappearances in El Salvador: an El Faro investigation. InSight crime. Investigation and analysis of organized crime. http://www.insightcrime.org/news-analysis/the-murky-questionof-disappearances-in-el-salvador-an-el-faro-investigation. Accessed 12 Nov 2015.

US Department of State. (2016). El Salvador travel warning. https://travel.state. gov/content/passports/en/alertswarnings/el-salvador-travel-warning. html Accessed 4 July 2016.

Wolf, S. (2011). Maras. In T. Bruneau, L. Danmert, \& E. Skinner (Eds.), Maras: gang violence and security in Central America (pp. 44-69). Austin: University of Texas Press.

\section{Submit your manuscript to a SpringerOpen ${ }^{\odot}$ journal and benefit from:}

- Convenient online submission

Rigorous peer review

Immediate publication on acceptance

- Open access: articles freely available online

- High visibility within the field

- Retaining the copyright to your article

Submit your next manuscript at springeropen.com 